PROBLEMS

OF EDUCATION IN THE $21^{\text {st }}$ CENTURY Vol. 80 , No. 1, 2022

52

\title{
IMPACT OF EXPERIENCING EVENT DESIGN WITH WEB 2.0 TOOLS ON PROSPECTIVE MATHEMATICS TEACHERS
}

\author{
Aybige Arabaci, Keziban Orbay \\ Amasya University, Turkey \\ E-mail: aybige9045@gmail.com, keziban.orbay@amasya.edu.tr
}

\begin{abstract}
In this study, the impact of activity designing experiences with Web 2.0 tools on prospective math teachers was examined. The aim of the study was to examine the impact of activity design experiences organized with Web 2.0 tools in the mathematics teaching course on the technological pedagogical content efficacy of prospective teachers, their attitude towards teaching technologies, and rapid content development selfefficacy with Web 2.0 tools. In the study, a nested mixed method was employed. In the study conducted with 33 prospective teachers from the primary mathematics teaching department, the quantitative data was collected using the scales "Technological Pedagogical Content Knowledge", "Self-Sufficiency for Web 2.0 Rapid Content Development" and "Attitude to Teaching Technologies". Qualitative data was collected using an interview form. Within the scope of the distance education and "Teaching numbers" course, different Web 2.0 tools were introduced for a period of 10 weeks, and it was presented how to create activity examples that could be used in mathematics teaching. According to the quantitative results, the prospective mathematics teachers'self-efficacy increased for rapid content development with Web 2.0 tools. In addition, it was observed that the "Attitude towards Teaching Technologies" scale had a significant effect on the sub-dimensions such as believing in the use of teaching technologies in lessons, enjoying the use of teaching technologies in lessons, and not enjoying the use of teaching technologies. In line with the opinions of prospective mathematics teachers, it was concluded that the study raised awareness about technology integration, enabled content production with Web 2.0 tools, and developed positive attitudes, new knowledge, and skills about technology.
\end{abstract}

Keywords: mathematics education, teaching numbers, distance education, teaching technology, web 2.0 tools.

\section{Introduction}

Today, rapid development and changes in information and communication technologies have affected many areas as well as educational environments which include the process of creating, structuring, and adapting information to daily life. These rapid changes and variations in technology and education have led teachers to think about the arrangements they need to implement to best prepare students for the 21 st century (Solomon \& Schrum, 2007), and technology integration in modern societies has become the basic need expected of teachers (Teo, 2009). Accordingly, prospective teachers should be prepared by teacher trainers in a way to transfer their knowledge to digital natives and the internet generation in 21st century classrooms (Kumar \& Vigil, 2011). In order for technology to be integrated in accordance with education, teachers need to be able to integrate information and communication technologies into their content and pedagogical knowledge without problems.

One of the factors affecting the use of technology in prospective teachers' future professional lives is the knowledge and skills they develop during undergraduate education (Anthony \& Clark, 2011; Niess, 2005; Özgün Koca, 2009). Therefore, teacher training programs should offer prospective teachers the opportunity to develop skills, strategy and awareness required to plan an effective education enriched with technology in their professional lives 
(Niess, 2008), and these programs should offer the opportunity to experience rich educational experiences for prospective teachers who do not have sufficient experience in planning and using educational technologies in teaching (Kovalik et al., 2013), although they can comfortably use technology for social networking, communication and entertainment in their personal lives (Niess, 2008).

Teacher trainers, who are the best predictors to combine pedagogy, self-sufficiency and beliefs with technology in their classrooms, need to improve preliminary knowledge and existing perceptions of prospective teachers in courses and professional development teaching provided (Wilson et al., 2005). Web 2.0 tools, which are one of the best technologies that can be integrated into education today, offer teachers alternative digital applications that can enable their professional development without time and space restrictions (Dalgarno \& Lee, 2010). Yusop (2015) indicated that researchers focus on factors that influence the use of Web 2.0 technologies by educators, and that educators' beliefs, intentions and attitudes towards technology are important determinants for future successful technology integration. Accordingly, it will be useful to see the reflection of technology-assisted teachings that will improve field knowledge, self-proficiency perception and attitudes of prospective mathematics teachers.

Web 2.0 technologies are tools that enable individuals to create content on the web and collaborate by eliminating geographical and temporal differences (O'reilly, 2007). Although these technologies were not originally designed for education, they offer both collaborative learning and individual learning opportunities for students (Hsu et al., 2014). Their use in the classroom not only promotes structuring learning, but also expands the content of traditional teaching and forms the bridge between theory and practice (Clark et al, 2009). Web 2.0 activates the student by providing opportunities such as information creation, production, editing and evaluation, and improves their self-confidence (McLoughlin \& Lee, 2007). In addition, the correct and appropriate use of these tools in education can excite and encourage students to learn as they raise awareness of group work and improve their collaboration skills (Crook, 2012; Mason \& Rennie, 2007).

Ensuring that students are willing to learn and evaluate through various activities is one of the main characteristics of successful math teachers. Web 2.0 tools provide teachers with significant opportunities for this. Web 2.0 tools commonly used in education include ToonyTool (cartoon app), Popplet (concept map app), Cram (game app), Quiver (augmented reality app), Learning Apps (various educational games app), Padlet (digital dashboard app), Toontastic (cartoon and animation app), Storyjumper (digital story and magazine app), Prezi (presentation app), Quizizz (evaluation app), Plickers (evaluation app) and The Math Learning Center (math applications). These Web 2.0 tools allow teacher to input data and produce multimedia products using text, audio, video, and graphics, limiting creativity and diversity. However, it is also very important to check the quality of the content created with these applications. Erroneous and low-quality content will not be effective in achieving the desired success in education.

The 5E model developed by Rodger Bybee, which is also recommended in this study, is one of the most effective teaching models included in the constructivist approach. It consists of five steps. These steps are Engage, Explore, Explain, Elaborate, and Evaluate, respectively. Each step has a certain function in itself. Each step provides opportunities to help the teacher improve learning activities and guide students through the learning process (Bybee et al., 2006).

\section{Literature Review}

Examining the field literature, there are studies aimed towards determining prospective teachers' opinions and intentions regarding the use of Web 2.0 tools (Bozkurt \& Cilavdaroğlu, 2011; Chiou, 2011; Dalim et al., 2019; Erduran, 2019; Günbaş \& Y1ldız, 2020; Korucu et al., 
PROBLEMS

OF EDUCATION IN THE $21^{\text {st }}$ CENTURY Vol. 79 , No. 6, 202

2015; Kul \& Çelik 2018; Lim \& Newby, 2020; Özçakır \& Aydın, 2019; Özpınar, 2017; Pala \& Erdem, 2015; Sadaf et al., 2012; Say \& Yildirim, 2020; Virtanen \& Rasi, 2017). These studies generally focus on all prospective teachers and a single type of application in field-specific studies, not specific to the field. For this reason, it is important to plan a pre-service training that will contribute to the development of technological pedagogical knowledge in the field of mathematics, which is compatible with the curriculum and will serve different purposes, and that allows gaining experience in designing activities. Habre and Grundmeier (2007) have indicated in their study that prospective teachers' experiences with the use of technology are important, and that their inadequate experience can influence their views on integrating technology into mathematics and prevent them from becoming aware of their own potential in a pedagogical sense. Many researchers have suggested that it is the responsibility of the teacher training programs to gain technological experience that will enable prospective teachers to increase their field knowledge, skills and beliefs in integrating technology into mathematics and to understand how to use it in mathematics teaching (Agyei \& Voogt, 2012; Erdogan \& Sahin, 2010; Hofer \& Grandgenett, 2012; Niess, 2005; Sadaf et al., 2012). Technology integration will be needed more because distance education is continued instead of face-to-face education during the Covid-19 pandemic, and online education will be a part of education after this process. For this reason, it is of great importance to examine the impact of the experiences of prospective teachers who will implement future curricula on them in developing and implementing materials to support online education. In this context, the impact of the experience of designing course activities using Web 2.0 tools suitable for the $5 \mathrm{E}$ model of prospective math teachers on their field competencies was examined in this study. Thus, in the context of the intended teaching, it will be revealed how the skills and perceptions of prospective math teachers to effectively integrate technology and pedagogy are affected. This study is unique to the field of mathematics, covers many Web 2.0 applications, and includes an experience of designing activities in accordance with the curriculum.

\section{Research Aim and Research Questions}

The study is based on the question "Does experiencing event design using Web 2.0 tools in accordance with model $5 \mathrm{E}$ have an impact on some field qualifications of prospective math teachers?" Accordingly, the answers to the following questions were searched:

With regard to the application of mathematics teaching course activities organized with Web 2.0 tools in accordance with the $5 \mathrm{E}$ model;

RQ1. What is the impact on prospective teachers' levels of Self-Efficacy towards Web 2.0 Rapid Content Development (SEW2RCD) and its dimensions?

RQ2. What is the impact on prospective teachers' levels on Technological Pedagogical Content Knowledge (TPCK) and its dimensions?

RQ3. What is the impact on prospective teachers' levels on Attitude towards Teaching Technologies (ATT) and its dimensions?

RQ4. What is the impact on the opinions of prospective teachers?

\section{Research Methodology}

\section{Pattern}

The study was conducted using the nested mixed method, one of the mixed research patterns. Many data types from nested mixed methods, either quantitative or qualitative, were collected and used together sequentially or simultaneously, and they were used in a way to support each other (Creswell, 2014). In the quantitative part, a single-group pre-test-final test 
pattern was preferred, and in the qualitative part, a case study approach was preferred. In the Vol. 79, No. 6, 2021 fall semester of the 2020-2021 academic year, preliminary tests were first performed and then trainings were carried out. Subsequently, the course plans prepared by the participants were evaluated, feedbacks were made, and final tests were applied. Finally, a structured interview was conducted.

\section{Study Group}

In the fall semester of the 2020-2021 academic year, the study was carried out with 33 prospective teachers in the $3 \mathrm{rd}$ grade of the Elementary Mathematics Teaching program at a public university. It was accepted that prospective teachers could carry out activities within the scope of the study and had the necessary pedagogical foundations due to the Teaching Technologies, Teaching Principles and Methods, Mathematics Learning and Teaching Approaches, Secondary School Mathematics Curricula, Information Technologies and Computer Aided Mathematics Teaching courses they received in previous periods. Due to the complete interruption of faceto-face training during the Covid-19 process, technological infrastructure deficiencies in the targeted groups and limited number of participants in the research, the number of participants was small. This situation is indicated in limitations section. Taking into account ethical understanding, the names of the participants are encoded as "PT1, PT2, PT3,...". Demographic characteristics of participants are presented in Table 1.

\section{Table 1}

Demographic Background of the Participants

\begin{tabular}{llll}
\hline & Category & Frequency (f) & Percent (\%) \\
\hline \multirow{2}{*}{ Gender } & Female & 29 & 87.9 \\
\cline { 2 - 4 } & Male & 4 & 12.1 \\
\hline \multirow{4}{*}{ Academic Achievement } & $70-74$ & 4 & 12.1 \\
\cline { 2 - 4 } & $75-79$ & 13 & 39.4 \\
\cline { 2 - 4 } & $80-84$ & 11 & 33.3 \\
\cline { 2 - 4 } Internet Access Tool & $85-90$ & 5 & 15.2 \\
\hline
\end{tabular}

It is seen from Table 1 that $87.9 \%$ of the participants are women, their academic average is concentrated in the range of $75-79$, and $90.9 \%$ access the Internet by mobile phone.

\section{Data Collection Tools}

In the collection of quantitative data, the following scales were used: the SEW2RCD scale developed by Birişçi et al. (2018) in order to establish the self-sufficiency beliefs of prospective teachers in rapid content development with Web 2.0 tools at different stages of the course; the Technological Pedagogical Content Knowledge (TPCK) scale developed by Schmidt et al. (2009) in order to determine the levels of technological pedagogical content knowledge and adapted to mathematics and Turkish by Dikkartın Övez and Akyüz (2013); Attitude to Teaching Technologies (ATT) scale developed by Metin et al. (2012). The Cronbach Alpha reliability coefficients of the scales used are 0.955 for the SEW2RCD scale, 0.91 for 
PROBLEMS

OF EDUCATION

IN THE $21^{\text {st }}$ CENTURY

Vol. $79, \frac{\text { No. } 6,2021}{56}$

the TPCK scale and 0.949 for the ATT scale. The interview form created to collect qualitative data was developed to describe the data obtained from quantitative data collection tools and analysis of course plans. The interview form was prepared by a math teacher who used Web 2.0 applications in his courses, taking into account the scales used and monitoring the teaching process. It was then examined and arranged by two field experts and finalized. The absence of a relationship of interest with the participants, long-term interaction and return to the prepared activities constituted an environment of trust. The data were gathered according to ethical guidelines for qualitative and quantitative research including the informed participant consent, guaranteed anonymity, and confidentiality.

\section{Application}

The study was carried out for 10 weeks within the scope of "Teaching Numbers" course in the 2020-2021 academic year. Due to the Covid-19 pandemic, the subjects in "teaching numbers" curriculum were explained by the faculty member who carried out the course during distance education, and videos prepared by the researcher with related examples were shown to the students at the end of the course every week. Since the courses were also recorded in the university's distance education system, it was also possible to monitor these courses afterwards. In these videos, prospective teachers were presented with information about the use of 12 Web 2.0 tools that addressed different stages of mathematics teaching, how to create activities and how to integrate them into teaching.

\section{Data Analysis}

In the study, quantitative data analysis was carried out with SPSS 20.0 packaged software. Shapiro-Wilk test, Skewness and Q-Q graph were taken into account for the hypothesis of normality. "Dependent t-test" was used to examine the significance of the difference between pretest and post-test averages. Cohen's d formula was used for dependent t-test and the magnitude of the effect was calculated when the difference between averages was significant. The data obtained from the interview form was analysed by content analysis method. The reliability formula developed by Miles and Huberman (1994) was used to determine the reliability of the data obtained. Reliability was found to be $100 \%$ in the theme, $88.8 \%$ in categories and subcategories, and 95\% in encodings.

\section{Research Results}

Results on RQ1 are presented in Table 2.

Table 2

Prospective Teachers' SEW2RCD and Sub-dimensions Dependent Sample t-test Results

\begin{tabular}{|c|c|c|c|c|c|c|c|c|}
\hline SEW2RCD Scale and Sub-Dimensions & & $n$ & & $S D$ & $d f$ & $t$ & $p$ & Cohen's o \\
\hline \multirow{2}{*}{ SEW2RCD } & Pre-test & 33 & 3.09 & .72 & 32 & -5.321 & $<.005$ & .926 \\
\hline & Post-test & 33 & 3.94 & .56 & 32 & & & \\
\hline \multirow{2}{*}{ Preparation } & Pre-test & 33 & 2.95 & .71 & 32 & 6.227 & $<.005$ & 1.084 \\
\hline & Post-test & 33 & 3.90 & .57 & 32 & & & \\
\hline \multirow{2}{*}{ Presentation } & Pre-test & 33 & 3.43 & .98 & 32 & 1.931 & $>.005$ & \\
\hline & Post-test & 33 & 3.81 & .64 & 32 & & & \\
\hline \multirow{2}{*}{ Evaluation } & Pre-test & 33 & 3.22 & .83 & 32 & 4.999 & $<.005$ & .870 \\
\hline & Post-test & 33 & 4.21 & .71 & 32 & & & \\
\hline
\end{tabular}


When the arithmetic averages of the SEW2RCD scale for preparation, presentation and evaluation sub-dimensions were examined for prospective teachers before and after application, it was seen that there was an increase. It can be seen that this increase was statistically significant in SEW2RCD (-5.321), preparation (6.227) and evaluation (4.999), and considering the magnitude of effect, SEW2RCD (Cohen's $d=0.926>0.8$ ), preparation (Cohen's $d=1.084>0.8$ ) and evaluation (Cohen's $d=0.870>0.8$ ) had a significant effect. The increase in the subdivision of Presentation (1.931) is not statistically significant.

Results on RQ2 are presented in Table 3.

\section{Table 3}

Prospective Teachers' TPCK and Sub-dimensions Dependent Sample t-test Results

\begin{tabular}{|c|c|c|c|c|c|c|c|}
\hline TPCK Scale and Sub-Dimensions & & $n$ & & $S D$ & $d f$ & $t$ & $p$ \\
\hline \multirow{2}{*}{ TPCK } & Pre-test & 33 & 3.58 & .46 & 32 & -1.135 & $>.005$ \\
\hline & Post-test & 33 & 3.67 & .38 & & & \\
\hline \multirow{2}{*}{ Technology Knowledge } & Pre-test & 33 & 3.42 & .62 & 32 & .649 & $>.005$ \\
\hline & Post-test & 33 & 3.48 & .60 & 32 & & \\
\hline \multirow{2}{*}{ Mathematics Knowledge } & Pre-test & 33 & 3.56 & .48 & 32 & 1.081 & $>.005$ \\
\hline & Post-test & 33 & 3.66 & .53 & 32 & & \\
\hline \multirow[t]{2}{*}{ Mathematics Teaching Information } & Pre-test & 33 & 3.62 & .62 & 32 & .344 & $>.005$ \\
\hline & Post-test & 33 & 3.66 & .53 & 32 & & \\
\hline \multirow{2}{*}{ Mathematics Teaching Technology Information } & Pre-test & 33 & 3.66 & .49 & 32 & 1.348 & $>.005$ \\
\hline & Post-test & 33 & 3.80 & .40 & 32 & & \\
\hline
\end{tabular}

When the arithmetic averages of prospective teachers before and after the application of TPCK scale and sub-dimensions such as Technology Knowledge, Mathematics Knowledge, Mathematics Teaching Information and Mathematics Teaching Technology Information were examined, there was an increase, but this increase was not statistically significant considering the results of the dependent sample t-test.

Results on RQ3 are presented in Table 4. 
Aybige ARABACI, Keziban ORBAY. Impact of experiencing event design with web 2.0 tools on prospective mathematics teachers

PROBLEMS

OF EDUCATION

IN THE $21^{\text {st }}$ CENTURY

Vol. 79 , No. 6, 202

Table 4

Prospective Teachers' ATT and Sub-dimensions Dependent Sample t-test Results

\begin{tabular}{lllllllll}
\hline ATT Scale and Sub-Dimensions & & $n$ & & SD & $\boldsymbol{d f}$ & $\boldsymbol{t}$ & $\boldsymbol{p}$ & Cohen's $\boldsymbol{d}$ \\
\hline \multirow{2}{*}{ ATT } & Pre-test & 33 & 3.13 & .27 & 32 & -1.450 & $>.005$ & \\
& Post-test & 33 & 3.19 & .20 & & & & \\
\hline Believing in the Use of Teaching & Pre-test & 33 & 3.93 & .57 & 32 & 2.549 & $<.005$ & .443 \\
Technologies in Courses & Post-test & 33 & 4.15 & .49 & 32 & & & \\
\hline Enjoying the Use of Teaching Technologies & Pre-test & 33 & 3.56 & .59 & 32 & 2.794 & $<.005$ & .486 \\
in Courses & Post-test & 33 & 3.83 & .42 & 32 & & & \\
\hline \multirow{2}{*}{ Distaste for the Use of Teaching } & Pre-test & 33 & 1.95 & .42 & 32 & -2.791 & $<.005$ & \multirow{2}{*}{.485} \\
Technologies & Post-test & 33 & 1.76 & .45 & 32 & & & \\
\hline Being Reluctant to Use Teaching & Pre-test & 33 & 2.59 & .37 & 32 & -.872 & $>.005$ & \\
Technologies & Post-test & 33 & 2.52 & .33 & 32 & & & \\
\hline Believing in the Benefits of Teaching & Pre-test & 33 & 4.30 & .57 & 32 & .584 & $>.005$ & \\
Technologies & Post-test & 33 & 4.36 & 065 & 32 & & & \\
\hline
\end{tabular}

When the arithmetic averages of prospective teachers before and after the application of the ATT scale were examined, it was seen that there was an increase in the positive subdimensions such as Believing in the Use of Teaching Technologies in Courses, Enjoying the Use of Teaching Technologies in Courses and Believing in the Benefits of Teaching Technologies, that there was a decrease in Distaste for the Use of Teaching Technologies and Being Reluctant to Use Teaching Technologies negative sub-dimensions. It can be seen that this change was statistically significant in Believing in the Use of Teaching Technologies in Courses (2.549), Enjoying the Use of Teaching Technologies in Courses (2.794) and Distaste for the Use of Teaching Technologies (2.791), and considering the magnitude of effect, Believing in the Use of Teaching Technologies in Courses (Cohen's $d=0.443<0.5$ ), Distaste for the Use of Teaching Technologies (Cohen's $d=0.485<0.5$ ) and Enjoying the Use of Teaching Technologies in Courses (Cohen's $d=0.486<0.5)$ had a small effect. In ATT $(-1.450)$, Being Reluctant to Use Teaching Technologies (-0.872) and Believing in the Benefits of Teaching Technologies (0.584), the change was not statistically significant.

The results of RQ4 were examined under three main themes including contributions, difficulties encountered, and the use of Web 2.0 tools based on codes determined from prospective teachers' answers to the questions in the interview form related to designing course activities. Categories, subcategories, and codes related to the "Contribution" theme are shown in Table 5. 
Table 5

Contributions of the Process of Designing Course Activities

\begin{tabular}{|c|c|c|c|c|}
\hline Category & Sub-Category & & Frequency $(f)$ & Percent $(\%)$ \\
\hline \multirow{7}{*}{$\begin{array}{l}\text { Mathematics } \\
\text { Teaching }\end{array}$} & \multirow{4}{*}{ Technology Integration } & Awareness & 18 & 26.87 \\
\hline & & Learning How to Use It & 8 & 11.94 \\
\hline & & Learning the Field of Use & 1 & 1.49 \\
\hline & & Ability to Produce Content & 5 & 7.46 \\
\hline & \multirow{3}{*}{$\begin{array}{l}\text { Pedagogical Content } \\
\text { Knowledge }\end{array}$} & Different Narration Methods & 3 & 4.48 \\
\hline & & Research Skills & 4 & 5.97 \\
\hline & & Measurement and Assessment & 1 & 1.49 \\
\hline \multirow{4}{*}{ Technology Use } & & $\begin{array}{c}\text { New Knowledge and Skills } \\
\text { Development }\end{array}$ & 8 & 11.94 \\
\hline & & Positive Attitude & 9 & 13.43 \\
\hline & & Self-confidence & 6 & 8.96 \\
\hline & & Saving Time & 4 & 5.97 \\
\hline
\end{tabular}

It is seen that the most important contribution of the process of designing course activities was awareness about technology integration, which is the subcategory of mathematics teaching. Prospective teachers indicated that they learned the function and opportunities of integrating technology into mathematics teaching, in which way, in which part of the course, and how often they will use the tools they chose. For example, the answer by PT6 is given below.

PT6: "When I was preparing the lesson plan, I realized for myself. Even the word file, which we consider the simplest and often use only for writing, has many functions and benefits for us to use in the course. Thanks to web 2.0 tools, I have seen that I can prepare and use many fun and useful content that I can use to enrich the course in an easy and interesting way using technology."

In the Pedagogical Content Knowledge subcategory in the mathematics teaching category, it was seen that the most important contribution was on research skills. Prospective teachers have indicated that the process of designing activities provided an increase in research skills, use of different narrative methods, and increase in knowledge of measurement and evaluation. As an example, Prospective Teacher 1 gave the following answer:

PT1: "The contribution of these tools, which simplistically simplistic technology for education, was that the only way to explain the course was to contribute to the course, which I could realize with more active student participation, contrary to the familiar methods."

In the category of the use of technology, it can be seen that the most important contribution was in positive attitude and new knowledge and skills development. Prospective teachers stated that they developed a positive attitude in the use of technology in the event preparation process, gained new knowledge and skills, gained confidence, and saved time. The answer given by PT18 is quite remarkable. 
Aybige ARABACI, Keziban ORBAY. Impact of experiencing event design with web 2.0 tools on prospective mathematics teachers

PROBLEMS

OF EDUCATION

IN THE $21^{\text {st }}$ CENTURY

Vol. 79 , No. 6, 2021

60

PT18: "I thought it was very difficult to create games and events in these programs. In fact, I loved it so much that I created activities and games other than what I put in my lesson plan. I am going to use it a lot in my life."

Encodings related to the theme "Challenges Encountered" is shown in Table 6.

\section{Table 6}

Challenges of Designing Course Activities

\begin{tabular}{lcc}
\hline & Frequency $(f)$ & Percent $(\%)$ \\
\hline 5E Model Stages & 3 & 8.33 \\
\hline Appropriate Narration Method & 4 & 11.11 \\
\hline Conceptual Knowledge and Narration & 2 & 5.56 \\
\hline Time Distribution & 3 & 8.33 \\
\hline Resource Discovery & 2 & 5.56 \\
\hline Preparing a Question & 6 & 16.67 \\
\hline Activity & 12 & 33.33 \\
\hline Content Determination & 2 & 5.56 \\
\hline Appropriate Web 2.0 Tool Selection & 2 & 5.56 \\
\hline
\end{tabular}

It is seen that the most difficult situation is in activity preparation. The answer of PT10 reflects the opinion of most prospective teachers.

PT10: "I can say that one of the points I am struggling with is the act of 'generating activity'. It really forced me to think of a safe, fun and instructive activity that was educationally useful, suitable for the functioning of the program, aimed at student achievements. I still do not feel comfortable with some of the activities I use. I know it is hard not only for me, but for all my friends, since our goal here is to have an event that can both have fun and teach, rather than a random event."

Categories and codes of the theme "Using Web 2.0 Tools" are shown in Table 7. 
Table 7

Use of Web 2.0 Tools in the Process of Designing Course Activities

\begin{tabular}{|c|c|c|c|}
\hline Category & & Frequency $(f)$ & Percent (\%) \\
\hline \multirow{5}{*}{ Tools Deemed Sufficient (Top 5) } & LearningApps & 14 & 13.46 \\
\hline & ToonyTool & 12 & 11.54 \\
\hline & Quizizz & 12 & 11.54 \\
\hline & Toontastic & 11 & 10.58 \\
\hline & Cram & 10 & 9.62 \\
\hline \multirow{5}{*}{ Tools Deemed Insufficient (Top 5) } & Story Jumper & 5 & 27.78 \\
\hline & Popplet & 3 & 16.67 \\
\hline & Padlet & 2 & 11.11 \\
\hline & Prezi & 2 & 11.11 \\
\hline & Plikers & 2 & 11.11 \\
\hline \multirow{5}{*}{ Preferred Tools (Top 5) } & Learning Apps & 16 & 34.04 \\
\hline & ToonyTool & 10 & 21.28 \\
\hline & Quizizz & 7 & 14.89 \\
\hline & Cram & 3 & 6.38 \\
\hline & Toontastic & 2 & 4.26 \\
\hline \multirow{5}{*}{$\begin{array}{l}\text { In the Implementation Process } \\
\text { Phase Used }\end{array}$} & Introduction & 7 & 14.29 \\
\hline & Discovering & 6 & 12.24 \\
\hline & Explanation & 6 & 12.24 \\
\hline & Deepening & 14 & 28.58 \\
\hline & Evaluation & 16 & 32.65 \\
\hline Using in Professional Life & Yes & 33 & 100 \\
\hline
\end{tabular}

It can be seen that the tools that prospective teachers consider themselves most adequate are Learning Apps, Toonytool and Quizizz, respectively, and the tools that prospective teachers consider themselves insufficient are Storyjumper and Popplet, respectively. In the process of designing course activities, the tools they consider sufficient are more than the tools they consider themselves inadequate. At the same time, it was determined that 4 of the vehicles deemed sufficient were tools that were not introduced to prospective teachers during the implementation process. Learning Apps, ToonyTool and Quizizz are also the most preferred tools for prospective teachers in the process of designing course activities, and the stages they use most are evaluation and deepening.

\section{Discussion}

The design process of mathematics teaching course activities has had an impact on the SEW2RCD of prospective teachers. Qualitative results obtained in line with the opinions of prospective teachers also support this thesis. It has been determined that the tools that prospective teachers consider themselves sufficient in the process of designing course activities are more than the tools they consider themselves inadequate, and four of the tools deemed sufficient are 
PROBLEMS

OF EDUCATION IN THE $21^{\text {st }}$ CENTURY Vol. 79, No. 6, 2021

62

tools that are not introduced to prospective teachers during the implementation process. Based on this, it is possible to suggest that prospective teachers have increased their self-sufficiency for Web 2.0 tools. When the literature is examined, there are studies that the experience of teaching technology integration courses, content development and event preparation using Web 2.0 tools increases teachers' self-sufficiency in learning and implementing teaching technologies (Gursoy \& Goksun, 2019; Onbaş111, 2020; Overbaugh \& Lu, 2008)

The design process of mathematics teaching course activities has improved all dimensions of the SEW2RCD scale for prospective teachers, while having more impact on the sub-dimensions of "Preparatory" and "Assessment". In their studies with prospective classroom and science teachers using the same scale, Gursoy and Goksun (2019) and Onbaş11 (2020) suggested that the experiences of prospective teachers using Web 2.0 tools had a meaningful effect on all dimensions of the SEW2RCD scale. Although this study's results regarding the sub-dimensions of "Preparation" and "Evaluation" are in line with these studies, they do not match the results regarding the sub-dimension of "Presentation". Considering the qualitative results, it has been determined that prospective teachers used web 2.0 tools in the "Introduction", "Deepening" and "Evaluation" stages in their course plans, and this situation served the subdimensions of "Preparation" and "Evaluation". Alhassan (2017) and Ward (2015) stated that there was a strong relationship between the use of Web 2.0 tools in classrooms and Web 2.0 tools self-proficiency beliefs. Therefore, it is expected that prospective teachers will develop self-sufficiency at the stages where they use Web 2.0 tools more.

There has been an increase in prospective mathematics teachers' TPCK levels and subdimensions before and after application, but this increase was not statistically significant. Analysing the studies suggesting that the processes carried out within the scope of training, courses, projects, etc. have improved at TPCK levels of prospective teachers (Agyei \& Voogt, 2012; Araujo \& Gadanidis, 2020; Bhagat et al., 2017; Hardy, 2010; Koyunkaya, 2017; Kul et al., 2019; Niess, 2005), it was observed that collaborative, active discussion environments were provided both face-to-face and online for prospective teachers, and they were offered the opportunity to apply in the teaching environment. The Covid-19 pandemic has restricted the study researchers from providing all the aforementioned opportunities to prospective teachers in this study conducted with distance education. Moreover, since pedagogy and technology can be best organized with collaborative studies in the classroom environment (Bull et al., 2007; Koehler \& Mishra, 2007); it may be possible that a significant increase could not be achieved in TPCK levels of prospective teachers.

Since not only scales are sufficient in measuring TPCK but it should be supported by multiple data sources (Abbitt, 2011; Agyei \& Keengwe, 2014; Lyublinskaya \& Tournaki, 2015), when qualitative results are examined, it is observed that the process of designing course activities has contributed to "awareness", "learning the way of use", "content reproducing", "new knowledge and skills development" and "self-confidence" for prospective mathematics teachers. It can be said that prospective teachers' gaining awareness has positively affected TPCK levels in the process of designing mathematics activity. The ability to produce the content that prospective teachers will apply to their lesson plans indicates that they have improved in terms of technology integration, while their confidence in the use of technology and gaining new knowledge and skills indicates that they have developed in terms of technology knowledge. In this case, it can be suggested that this study is effective in the development of TPCK levels of prospective teachers. Thompson (2007) has indicated that, thanks to the advantages of Web 2.0 tools and their useful interfaces, users can produce content without difficulty. For this reason, in this study, ensuring that prospective teachers are aware of the mathematical activities that can be created with Web 2.0 tools may have improved prospective teachers' perception of being able to produce content. 
Prospective teachers have difficulty in preparing lesson plans. Considering that pedagogical content knowledge is defined as the ability to select and effectively organize teaching strategies and practices specific to the subject content to be taught (Mishra \& Koehler, 2006), it is seen that prospective teachers have difficulties in the pedagogical content knowledge dimension.

Considering the entire ATT scale, this increase was not statistically significant, although there was an increase in ATT levels when the design process of mathematics teaching course activities and the attitude of prospective teachers towards teaching technologies were taken into account before and after implementation. It was observed that there was an increase in the sub-dimensions of the ATT scale that measure positive attitudes and a decrease in negative sub-dimensions. Virtanen and Rasi (2017) also suggested that prospective teachers developed a positive perspective on integrating Web 2.0 tools into the course by integrating Web 2.0 applications into the "Problem-Based Learning" course, aiming to reveal the experiences and opinions of prospective teachers through case study.

\section{Conclusion and Implications}

It was concluded that the process of designing math activity with Web 2.0 tools has an impact on prospective teachers' SEW2RCD levels. Considering the sub-dimensions of the SEW2RCD scale, it was found that it was not effective in the "Presentation" sub-dimension, but it was effective on the sub-dimensions, "Preparation" and "Evaluation". In line with the opinions of prospective teachers, it was concluded that the tools they consider sufficient in the process of designing course activities are more than the tools they consider inadequate. It was concluded that prospective teachers may have high perceptions of SEW2RCD due to the fact that prospective teachers voluntarily learn and try new Web 2.0 tools outside of those introduced during the design process. Prospective teachers found themselves most inadequate in presentation tools, and they were all willing to use Web 2.0 tools in their professional lives.

The design process of mathematics teaching course activities did not have a meaningful impact on TPCK and all sub-dimensions of prospective teachers. However, prospective teachers gained awareness about the function and opportunities of technology in mathematics teaching. Integrating technology into mathematics teaching, prospective teachers learned how to use the tools, in which part of the course and how often, they were able to produce content with Web 2.0 tools, they developed new knowledge, skills and a sense of self-confidence about the use of technology. However, prospective teachers have difficulty in creating creative, engaging and stage-appropriate activities that are suitable for the student level. At the same time, it has been found in the study that prospective teachers have difficulty in preparing questions that are appropriate to students' levels, offer a variety of questions, make use of acquisitions well, make connection between students' preliminary information and the information they have just learned, and determine the appropriate narrative method that will allow the subject to be better conveyed in accordance with the students' readiness and individual differences. In addition, the time distribution and the 5E model are among the situations where prospective teachers have difficulty in applying.

Considering the entire ATT scale, although the design process of mathematics teaching course activities showed no effects on prospective teachers' attitudes towards teaching technologies, when sub-dimensions of this scale were examined, the belief in the use of teaching technologies and enjoyment of the use of teaching technologies were positively affected. The arithmetic average of the entire scale and a sub-dimension measuring positive attitude increased, although not significantly. There has been a decrease in arithmetic averages of the sub-dimension that measures negative attitude, although not significantly. In addition, considering prospective teachers' average scores from the ATT scale and its sub-dimensions 
PROBLEMS

OF EDUCATION

IN THE $21^{\text {st }}$ CENTURY

Vol. 79 , No. 6,2021

before the application, it was observed that prospective teachers used to have a moderate and good positive attitude before the application. Therefore, this may explain why the increase after the application is statistically significant. Considering the qualitative results, the vast majority of prospective teachers stated that the study process contributed to the use of technology, and they gained a positive attitude.

Since the use of technology in education is now a must with the Covid-19 pandemic process, teachers should be given in-service training related to the use of Web 2.0 tools to prepare for situations that may be needed such as the pandemic process, and by integrating teaching technologies into the different curricula of faculty members working in education faculties, it can be ensured that prospective teachers are aware of various Web 2.0 tools that serve different purposes and achievements. In the future, including Web 2.0 tools, studies can also be carried out on the examination of some field qualifications of prospective teachers using a blended teaching method that combines distance education with face-to-face education, or by using technology-assisted micro-teaching applications. Similar studies can be done comparatively for teachers and prospective teachers. This study was carried out within the scope of "Teaching Numbers" course. The change can also be examined within the scope of "Geometry Teaching" course.

\section{Limitations}

This research is limited to 33 teacher candidates who studied in the third year of Primary Mathematics Teaching at a public university in the 2020-2021 academic year and took the course "Teaching numbers". In addition, the teaching process is limited to a total of 10 weeks of distance education.

\section{Ethical Approval}

The data were gathered according to ethical guidelines for qualitative research including informed participant consent, guaranteed anonymity, and confidentiality (The Unit of Ethics of Amasya University with Reference Number 674).

\section{Declaration of Interest}

Authors declare no competing interest.

\section{Acknowledgments}

The authors would like to thank the anonymous referees for their encouraging comments and insightful suggestions, which helped to improve the quality of the research substantially.

\section{References}

Abbitt, J. T. (2011). Measuring technological pedagogical content knowledge in preservice teacher education: A review of current methods and instruments. Journal of Research on Technology in Education, 43(4), 281-300. https://doi.org/https://doi.org/10.1080/15391523.2011.10782573

Agyei, D. D., \& Keengwe, J. (2014). Using technology pedagogical content knowledge development to enhance learning outcomes. Education and Information Technologies, 19(1), 155-171. https://doi.org/https://doi.org/10.1007/s10639-012-9204-1

Agyei, D. D., \& Voogt, J. (2012). Developing technological pedagogical content knowledge in preservice mathematics teachers through collaborative design. Australasian Journal of Educational Technology, 28(4), 547-564. https://doi.org/https://doi.org/10.14742/ajet.827 
Alhassan, R. (2017). Exploring the relationship between Web 2.0 tools self-efficacy and teachers' use of these tools in their teaching. Journal of Education and Learning, 6(4), 217-228. https://doi.org/http://doi.org/10.5539/jel.v6n4p217

Anthony, A. B., \& Clark, L. M. (2011). Examining dilemmas of practice associated with the integration of technology into mathematics classrooms serving urban students. Urban Education, 46(6), 13001331. https://doi.org/https://doi.org/10.1177/0042085911416015

Araujo, R. C., \& Gadanidis, G. (2020). Online collaborative mind mapping in a mathematics teacher education program: A study on student interaction and knowledge construction. ZDM, 52(5), 943 958. https://doi.org/https://doi.org/10.1007/s11858-019-01125-w

Bhagat, K. K., Chang, C.-Y., \& Huang, R. (2017). Integrating GeoGebra with TPACK in improving pre-service mathematics teachers' professional development. 2017 IEEE 17th International Conference on Advanced Learning Technologies (ICALT).

Birişçi, S., Kul, Ü., Aksu, Z., Akaslan, D., \& Çelik, S. (2018). A scale development study to determine Web 2.0 practical content development self-efficacy belief(W2SEBS). Educational Technology Theory and Practice Journal, 8(1), 187-208. https://doi.org/https://doi.org/10.15345/iojes.2019.01.014

Bozkurt, A., \& Cilavdaroğlu, A. K. (2011). Mathematics and classroom teachers' perceptions of technology use and integration into their instruction. Kastamonu Education Journal, 19(3), 859870. https://dergipark.org.tr/en/pub/kefdergi/issue/49049/625724

Bull, G., Park, J., Searson, M., Thompson, A., Mishra, P., Koehler, M. J., \& Knezek, G. (2007). Developing technology policies for effective classroom practice. Contemporary Issues in Technology and Teacher Education, 7(3), 129-139. https://www.learntechlib.org/primary/p/26276/.

Bybee, R. W., Taylor, J. A., Gardner, A., Van Scotter, P., Powell, J. C., Westbrook, A., \& Landes, N. (2006). The BSCS 5E instructional model: Origins and effectiveness. https://media.bscs.org/ bscsmw/5es/bscs_5e_full_report.pdf

Chiou, Y.-F. (2011). Perceived usefulness, perceive ease of use, computer attitude, and using experience of Web 2.0 applications as predictors of intent to use Web 2.0 by pre-service teachers for teaching (Publication Number 3466156) [Ph.D., Ohio University]. ProQuest Dissertations \& Theses Global. Ann Arbor. https://www.proquest.com/dissertations-theses/perceived-usefulness-perceive-easeuse-computer/docview/901907862/se-2?accountid=25074

Clark, W., Logan, K., Luckin, R., Mee, A., \& Oliver, M. (2009). Beyond Web 2.0: Mapping the technology landscapes of young learners. Journal of computer assisted learning, 25(1), 56-69. https://doi.org/https://doi.org/10.1111/j.1365-2729.2008.00305.x

Creswell, J. W. (2014). Nitel, nicel araştırma deseni ve karma yöntem yaklaşımları [Qualitative, quantitative research design and mixed method approaches] (S. B. Demir, Çev. Ed.). Eğiten Kitap.

Crook, C. (2012). The 'digital native' in context: Tensions associated with importing Web 2.0 practices into the school setting. Oxford Review of Education, 38(1), 63-80. https://doi.org/https://doi.org/10.1080/03054985.2011.577946

Dalgarno, B., \& Lee, M. J.(2010). What are the learning affordances of 3-D virtual environments? British Journal of Educational Technology, 41(1), 10-32. https://doi.org/https://doi.org/10.1111/j.1467-8535.2009.01038.x

Dalim, S. F., Azliza, N. Z. M., Ibrahim, N., Zulkipli, Z. A., \& Yusof, M. M. M. (2019). Digital storytelling for 21st century learning: A study on pre-service teachers' perception. Asian Journal of University Education, 15(3), 226-234. https://doi.org/https://doi.org/10.24191/ajue.v15i3.7801

Dikkartin Övez, F. T., \& Akyüz, G. (2013). Modelling technological pedagogical content knowledge constructs of preservice elementary mathematics teachers. Education and Science, 38(170), 321-334. http://dspace.balikesir.edu.tr/xmlui/bitstream/handle/20.500.12462/9128/filiz-tuba. pdf? sequence $=2 \&$ is Allowed $=\mathrm{y}$

Erdogan, A., \& Sahin, I. (2010). Relationship between math teacher candidates' technological pedagogical and content knowledge (TPACK) and achievement levels. Procedia-Social and Behavioral Sciences, 2(2), 2707-2711. https://doi.org/https://doi.org/10.1016/j.sbspro.2010.03.400

Erduran, A. (2019). Pre-service mathematics teachers' views on formative valuation with Web 2.0 tools: Kahoot! example. In International Symposium of Turkish Computer and Mathematics Education. İzmir.

Gursoy, G., \& Goksun, D. O. (2019). The experiences of pre-service science teachers in educational content development using Web 2.0 tools. Contemporary Educational Technology, 10(4), 338357. https://doi.org/https://doi.org/10.30935/cet.000000 
PROBLEMS

OF EDUCATION IN THE $21^{\text {st }}$ CENTURY Vol. 79, No. 6,2021

Günbas, N., \& Yıldız, H. (2020). Use of Edmodo social networking website in mathematics curriculum class: Pre-service teachers' views. Journal of Bayburt Education Faculty, 15(29), 109-129. https://doi.org/https://doi.org/10.35675/befdergi.478788

Habre, S., \& Grundmeier, T. A. (2007). Prospective mathematics teachers' views on the role of technology in mathematics education. Issues in the Undergraduate Mathematics Preparation of School Teachers, 3. http://files.eric.ed.gov/fulltext/EJ835509.pdf

Hardy, M. D. (2010). Facilitating growth in preservice mathematics teachers' TPCK. National Teacher Education Journal, 3(2), 121-138. https://www.researchgate.net/publication/282877535

Hofer, M., \& Grandgenett, N. (2012). TPACK development in teacher education: A longitudinal study of preservice teachers in a secondary MA Ed. program. Journal of research on Technology in Education, 45(1), 83-106. https://doi.org/ttps://doi.org/10.1080/15391523.2012.10782598

Hsu, Y., Ching, Y., \& Grabowski, B. L. (2014). Web 2.0 applications and practices for learning through collaboration. In Handbook of research on educational communications and technology (pp. 747758). Springer. https://doi.org/https://doi.org/10.1007/978-1-4614-3185-5 60

Koehler, M. J., Mishra, P., \& Yahya, K. (2007). Tracing the development of teacher knowledge in a design seminar: Integrating content, pedagogy and technology. Computers \& Education, 49(3), 740-762. https://doi.org/https://doi.org/10.1016/j.compedu.2005.11.012

Korucu, A., Korucu, A. T., \& Çakır, H. (2015). The opinions of the teacher candidates using collaborative learning environment developed via dynamic web technologies. Adiyaman University Journal of Social Sciences, (19), 221-254. https://doi.org/https://doi.org/10.14520/adyusbd.61147

Kovalik, C., Kuo, C.-L., \& Karpinski, A. (2013). Assessing preservice teachers' information and communication technologies knowledge. Journal of Technology and Teacher Education, 21(2), 179-202. https://www.learntechlib.org/primary/p/40634/

Koyunkaya, M. Y. (2017). A teaching experiment that aims to develop pre-service mathematics teachers' technological pedagogical and content knowledge. Turkish Journal of Computer and Mathematics Education, 8(2), 284-322. https://doi.org/https://doi.org/10.17762/turcomat.v8i2.157

Kul, U., Aksu, Z., \& Birisci, S. (2019). The relationship between technological pedagogical content knowledge and Web 2.0 self-efficacy beliefs. Online Submission, 11(1), 198-213. https://files.eric.ed.gov/fulltext/ED593344.pdf

Kul, Ü., \& Çelik, S. (2018). Investigating changes in mathematics teachers' intentions regarding web 2.0 technology integration. Acta Didactica Napocensia, 11(2), 89-104. https://files.eric.ed.gov/fulltext/EJ1185876.pdf

Kumar, S., \& Vigil, K. (2011). The net generation as preservice teachers: Transferring familiarity with new technologies to educational environments. Journal of Digital Learning in Teacher Education, 27(4), 144-153. https://doi.org/https://doi.org/10.1080/21532974.2011.10784671

Lim, J., \& Newby, T. J. (2020). Preservice teachers' Web 2.0 experiences and perceptions on Web 2.0 as a personal learning environment. Journal of Computing in Higher Education, 32(2), 234-260. https://doi.org/https://doi.org/10.1007/s12528-019-09227-w

Lyublinskaya, I., \& Tournaki, N. (2015). Examining the relationship between self and external assessment of TPACK of pre-service special education teachers. In L. Liu, \& D. Gibson (Eds.), Research Highlights in Technology and Teacher Education 2015. AACE-Association for the Advancement of Computing in Education.

Mason, R., \& Rennie, F. (2007). Using Web 2.0 for learning in the community. The Internet and Higher Education, 10(3), 196-203. https://doi.org/10.1016/j.iheduc.2007.06.003

McLoughlin, C., \& Lee, M. (2007). Social software and participatory learning: Pedagogical choices with technology affordances in the Web 2.0 era. ICT: Providing choices for learners and learning. In R. Atkinson, C. McBeath, \& A. Soong Swee Kit (Eds.), ICT: Providing choices for learners and learning. Proceedings ASCILITE Singapore 2007 (pp. 664-675). Centre for Educational Development.

Metin, M., Kaleli Yilmaz, G., Coskun, K., \& Birisci, S. (2012). Developing an attitude scale towards using instructional technologies for pre-service teachers. Turkish Online Journal of Educational Technology-TOJET, 11(1), 36-45. https://files.eric.ed.gov/fulltext/EJ976568.pdf

Miles, M. B., \& Huberman, A. M. (1994). Qualitative data analysis: An expanded sourcebook. Sage.

Mishra, P., \& Koehler, M. J. (2006). Technological pedagogical content knowledge: A framework for teacher knowledge. Teachers College Record, 108(6), 1017-1054. http://one2oneheights.pbworks. com/f/MISHRA_PUNYA.pdf 
Niess, M. L. (2005). Preparing teachers to teach science and mathematics with technology: Developing a technology pedagogical content knowledge. Teaching and Teacher Education, 21(5), 509-523. https://doi.org/https://doi.org/10.1016/j.tate.2005.03.006

Niess, M. L. (2008). Guiding preservice teachers in developing TPCK. In M. C. Herring, M. J. Koehler, \& P. Mishra (Eds.), Handbook of technological pedagogical content knowledge (TPCK) for educators (pp. 223-250). AACTE Committee on Innovation and Technology. New York: Routledge for the American Association of Colleges for Teacher Education.

O'reilly, T. (2007). What is Web 2.0: Design patterns and business models for the next generation of software. Communications \& Strategies (1), 17.

Onbaşı1ı, Ü. I. (2020). The effects of science teaching practice supported with Web 2.0 tools on prospective elementary school teachers' self-efficacy beliefs. International Journal of Progressive Education, 16(2), 91-110. https://files.eric.ed.gov/fulltext/EJ1249937.pdf

Overbaugh, R., \& Lu, R. (2008). The impact of a NCLB-EETT funded professional development program on teacher self-efficacy and resultant implementation. Journal of Research on Technology in Education, 41(1), 43-61. https://files.eric.ed.gov/fulltext/EJ810574.pdf

Özçakır, B., \& Aydın, B. (2019). Effects of augmented reality experiences on technology integration self-efficacy of prospective mathematics teachers. Turkish Journal of Computer and Mathematics Education, 10(2), 314-335. https://doi.org/https://doi.org/10.16949/turkbilmat.487162

Özgün Koca, S. A. (2009). The views of preservice teachers about the strengths and limitations of the use of graphing calculators in mathematics instruction. Journal of Technology and Teacher Education, 17(2), 203-227. https://www.learntechlib.org/primary/p/26268/

Özpınar, İ. (2017). Preservice mathematics teachers' opinions on the use of digital stories and instructional environments. Bartin University Journal of Faculty of Education, 6(3), 11891210. https://doi.org/https://doi.org/10.14686/buefad.340057

Pala, F. K., \& Erdem, M. (2015). Opinions of pre-service teachers on online discussion environments. Turkish Online Journal of Qualitative Inquiry, 6(2), 24-47. https://doi.org/https://doi.org/10.17569/tojqi.12373

Sadaf, A., Newby, T. J., \& Ertmer, P. A. (2012). Exploring pre-service teachers' beliefs about using Web 2.0 technologies in K-12 classroom. Computers \& Education, 59(3), 937-945. https://doi.org/https://doi.org/10.1016/j.compedu.2012.04.001

Say, S., \& Yildirim, F. S. (2020). Investigation of pre-service teachers' Web 2.0 rapid content development self-efficacy belief levels and their views on Web 2.0 tools. International Journal of Educational Methodology, 6(2), 345-354. https://doi.org/https://doi.org/10.12973/ijem.6.2.345

Schmidt, D. A., Baran, E., Thompson, A. D., Mishra, P., Koehler, M. J., \& Shin, T. S. (2009). Technological pedagogical content knowledge (TPACK) the development and validation of an assessment instrument for preservice teachers. Journal of Research on Technology in Education, 42(2), 123 149. https://files.eric.ed.gov/fulltext/EJ868626.pdf

Solomon, G., \& Schrum, L. (2007). Web 2.0: New tools, new schools. International Society for Technology Education.

Teo, T. (2009). Examining the relationship between student teachers' self-efficacy beliefs and their intended uses of technology for teaching: A structural equation modelling approach. Turkish Online Journal of Educational Technology-TOJET, 8(4), 7-15. https://files.eric.ed.gov/fulltext/EJ859493.pdf

Thompson, J. (2007). Is Education 1.0 ready for Web 2.0 students? Innovate: Journal of Online Education, 3(4). https://www.learntechlib.org/p/104227/

Virtanen, J., \& Rasi, P. (2017). Integrating web 2.0 technologies into face-to-face PBL to support producing, storing, and sharing content in a higher education course. Interdisciplinary Journal of Problem-Based Learning, 11(1), 5. https://doi.org/https://doi.org/10.7771/1541-5015.1613

Ward, S. (2015). The impact of self-efficacy and professional development on implementation of web 2.0 tools in elementary classrooms. https://digitalcommons.gardner-webb.edu/education_etd/140

Wilson, P. S., Cooney, T. J., \& Stinson, D. W. (2005). What constitutes good mathematics teaching and how it develops: Nine high school teachers' perspectives. Journal of Mathematics Teacher Education, 8, 83-111. https://doi.org/10.1007/s10857-005-4796-7

Yusop, F. D. (2015). A dataset of factors that influence preservice teachers' intentions to use Web 2.0 technologies in future teaching practices. British Journal of Educational Technology, 46(5), 1075 1080. https://doi.org/10.1111/bjet.12330/abstract 
Aybige ARABACI, Keziban ORBAY. Impact of experiencing event design with web 2.0 tools on prospective mathematics teachers

PROBLEMS

OF EDUCATION

IN THE $21^{\text {st }}$ CENTURY

Vol. 79, No. 6, 2021

$\begin{array}{r}68 \\ \hline 68\end{array}$

Received: December 28, 2021

Accepted: February 08, 2022

Cite as: Arabaci, A., \& Orbay, K. (2022). Impact of experiencing event design with web 2.0 tools on prospective mathematics teachers. Problems of Education in the $21^{s t}$ Century, 80(1), 52-68. https://doi.org/10.33225/pec/22.80.52

Aybige Arabacı

(Corresponding author)
MSc, Mathematics Education Department, Faculty of Education, Amasya University, Amasya, Turkey.

E-mail: aybige9045@gmail.com

ORCID: https://orcid.org/ 0000-0002-4912-5782

PhD, Professor, Head of Mathematics Education Department, Faculty of Education, Amasya University, Amasya, Turkey.

E-mail: keziban.orbay@amasya.edu.tr

ORCID: https://orcid.org/ 0000-0002-7642-4139 